Process Waste Assessment Approach, Training, and Technical Assistance for DOE Contractors

Yansas City Division

Susan E. Pemberton

KCP-613-5137

Recervas

Published April 1993

APR 291933

OSTI 


\section{DISCLAIMER}

This repurt was prepared as an account of work sponsored by an agency of the United States Government. Neither the United States Government nor any agency thereof, nor any of their employees, makes any warranty, express or implied, or assumes any legal liability or responsibility for the accuracy, completeness, or usefulness of any information, apparatus, product, or process disclosed, or represents that its use would not infringe privately owned rights. Reference herein to any specific commercial product, process, or service by trade name, trademark, manufacturer, or otherwise, does not necessarily constitute or imply its endorsement, recommendation, or favoring by the United States Government or any agency thereof. The views and opinions of authors expressed herein do not necessarily state or reflect those of the United States Government or any agency thereof.

Printed in the United States of America.

This report has been reproduced from the best available copy.

Available to DOE and DOE contractors from the Office of Scientific and Technical Information, P. O. Box 62, Oak Ridge, Tennessee 37831; prices available from (615) 576-8401, FTS 626-8401.

Available to the public from the National Technical Information Service, U. S. Department of Commerce, 5285 Port Royal Rd., Springfield, Virginia 22161. 
KCP-613-5137

Distribution Category UC-700

PROCESS WASTE ASSESSMENT APPROACH, TRAINING, AND TECHNICAL ASSISTANCE FOR DOE CONTRACTORS

Susan E. Pemberton

Published April 1993

Paper submitted to Department of Energy Waste Minimization

Pollution Prevention Conference IX

April 13-15, 1993

San Francisco, CA 


\title{
Process Waste Assessment Approach, Training, \& Technical Assistance For DOE Contractors
}

\author{
Susan E. Pemberton \\ Materials Engineering \\ AlliedSignal Inc. \\ "Kansas City Division
}

\section{INTRODUCTION}

The Department of Energy is committed to the hazardous waste minimization requirements set forth under RCRA as amended by HSWA. These regulations required that generators of hazardous waste "have a program in place to reduce the volume and toxicity of waste generated to the extent that is economically practical." Therefore, the DOE issued two orders, 5400.1 and 5820.2A, to mandate that the management of radioactive wastes and other pollutants be accomplished in a manner that minimizes the generation of such wastes. These orders also required each DOE Operations Office to issue a waste minimization plan, thus giving the ownership of waste minimization to the waste generators.

Assessments of all waste-generating operations within the DOE were required as the initial phase of the formal waste minimization program. These assessments, called Process Waste Assessments (PWAs), identify the nature and amounts of waste from each process within a plant's operations, identify the opportunities that exist for pollution prevention, and then evaluate those opportunities for feasible implementation. Therefore, the PWAs enable each DOE site to identify those processes, operations, and procedures that need to be improved or replaced to promote pollution prevention and at the same time provide a baseline from which to measure the pollution prevention progress. In a nutshell, PWAs are the foundation upon which comprehensive and effective pollution prevention rests.

\section{FY91}

The development of PWAs at the "Kansas City Division of AlliedSignal Inc. was initiated in October 1990. A site-specific PWA Guidance that addresses pollutant releases to all environmental media, based on information in DOE's Model PWA Plan and EPA's Waste Minimization Opportunity Assessment Manual, was published by the Kansas City Plant (KCP). The KCP's designed PWA methodology streamlines regulatory reporting and tracking requirements.

In FY91, emphasis was first given to shop floor manufacturing operations with the completion of eight pilot PWAss. However, lessons learned from this development indicated a need to concentrate on an alternative approach for non-manufacturing processes.

- Operated for the United States Department of Energy under Contract No. DE-AC04-76-DP00613. 


\section{FY92}

Therefore, in FY92 a graded approach to perform PWAs was developed. This approach consists of three different PWA levels: Level $A$ is a full scope PWA, while Leveis $B$ and $C$ are reduced scope assessments requiring less effort. The graded approach establishes volume and toxicity thresholds for materials used in a given process. The actual volume and toxicity of a material determine the PWA level. For processes with a low volume of waste and/or less hazardous materials, the graded approach reduces the effort involved by decreasing the detail required in the material balance. Option generation and evaluation remains equivalent for all of the levels.

Two items are required for a successful PWA program: a structured methodology and training in its use. Therefore, a PWA training program for KCP personnel was also developed in FY92. This training is performance-based. The trainee first learns the steps of a PWA by walking through an example. Then, the students work in teams; each team completes its own PWA with an industrial process. To conclude, the students are given a written test covering the course objectives.

\section{FY93}

In response to needs expressed by contractors, DOE's Office of Environmental Restoration and Waste Management, Division of Waste Minimization, EM-352, asked the KCP to be the focal point of PWAs in the DOE complex through the project titled "Process Waste Assessment Approach, Training, and Technical Assistance." This project has three goals:

1. Development of a uniform graded approach with the flexibility to accommodate the wide variety of contractor activities,

2. Presentation of a performance-based training workshop to teach this methodology, and

3. Assistance to contractors with implementation efforts at their sites.

This paper will describe the schedule, deliverables, and status of the objectives in this project.

\section{PWA GRADED APPROACH}

The objectives for this activity are to (1) develop a uniform PWA graded approach applicable to both production and laboratory facilities in the DOE; (2) establish reasonable parameters to use in the graded approach such as material toxicity, waste quantity, and cost factors; (3) establish minimum requirements for the PWA levels; and (4) provide justification for informal PWNAs. A team has been formed consisting of the four Department of Energy Defense Programs (DP) laboratories -- LLNL, LANL, SNL/CA, and SNL/NM -- and a production facility, KCP, to achieve these objectives. The following are members of this team. 
Team Member

Susan Pemberton - Leader

Dave Eggers

Don Watson

Michael Meltzer

Jeff Weinrach

Alice Johnson-Duarte

Don Adolphson

Ed Kjeldgaard

Gordon Smith
Eacility

Kansas City Plant, (KCP)

Lawrence Livermore National

Labs, (LLNL)

Los Alamos National Labs, (LANL)

Sandia National Labs, Livermore, CA, (SNL/CA)

Sandia National Labs, Albuquerque, NM, (SNL/NM)

The team working on the PWA approach is following the total quality nine-step process.

Step 1. Identification of the key problem: A uniform PWA graded approach does not exist for the DOE contrantors.

Step 2. Team formation and establishment of customer requirements: see above.

Step 3. Analyze the current process: KCP's PWA graded approach.

Step 4. Define the desired outcomes: This is being accomplished through the development of a PWA needs assessment for each facility. These needs will be prioritized and then the team will determine how to achieve them.

Step 5. Icsentify root causes and propose solutions: Working together, the team will modify KCP's PWA graded approach methodology to satisfy the prioritized needs.

Step 6. Test proposed solutions: Projects will be selected to pilot the methodology, with a minimum of one at each DP laboratory facility being initiated in FY93.

Step 7. Refine and implement solutions.

Step 8. Measure progress.

Step 9. Acknowledge team and communicate results. 
The following schedule provides the initial planning and status for the objectives and deliverables for the graded approach activity.

Activity

Identify support personnel from each of the DOE's DP laboratories.

* Perform preliminary needs assessment at each of the selected laboratories.

* Modify KCP's PWA Graded Approach.

Propose and prioritize pilot PWA projects at each laboratory, consistent with their typical operations.

Initiate performance of pilot projects using modified PWA Graded Approach.

* Document FY93 efforts and lessons learned, and recommend future initiatives.

\section{End Date Status}

FY93-1 Complete

FY93-2 In Progress

FY93-3

FY93-3

FY93-4

FY93-4

* Deliverable

\section{PWA TRAINING}

The team working on this activity consists of the following KCP personnel:

Don Watson, Leader

Milt Bryant

Mike Gerding

Susan Pemberton

Joe Riehle

Bill Schlosberg

Linda Taylor

KCP will tailor the scope of its PWA training module to meet the needs of other interested DOE sites. A set of worksheets that leads the user through the methodology 
has been developed, and KCP's existing performance-based training program has been modified. A microcomputer-based system (both IBM and Macintosh compatible) has also been developed. Working with DOE-HQ, KCP will identify appropriate means to advertise the availability of KCP's training and technical assistance. This will include the development of a DOE-wide PWA contact list. Initially, three training courses, accommodating 20 to 25 people each, will be held on-site at the KCP. The scheduled dates are August 18-19, August 25-26, and September 1-2, 1993. Call Linda Taylor at 816-997-7233 if you are interested. Each attendee will be given the opportunity to complete an example PWA. A training workbook, model worksheets, and a diskette with the worksheet software will be provided.

\section{TECHNICAL ASSISTANCE}

The third part of this project is technical assistance. KCP will provide 500 hours of offsite technical assistance for those requesting aid. One of the major lessons learned is that the PWA process is only successful if generators have ownership of their processes. Therefore, KCP will only assist with defining requirements, facilitating teams of site personnel, and consulting and reviewing of PWAs.

The following schedule provides the initial planning and status for the objectives and deliverables for the training and technical assistance activities.

Activity

* Develop list of PWA contacts within DOE.

* Develop training module.

Invite interested DOE contractor personnel to attend training and volunteer off-site assistance.

Deliver on-site PWA training.

Provide off-site PWA technical assistance as requested.

- Document training and assistance through a final report and recommend future initiatives.

\section{End Date Status}

FY93-2 In Progress

FY93-3 In Progress

FY93-3

FY93-4

FY93-4

FY93-4

* Deliverable 

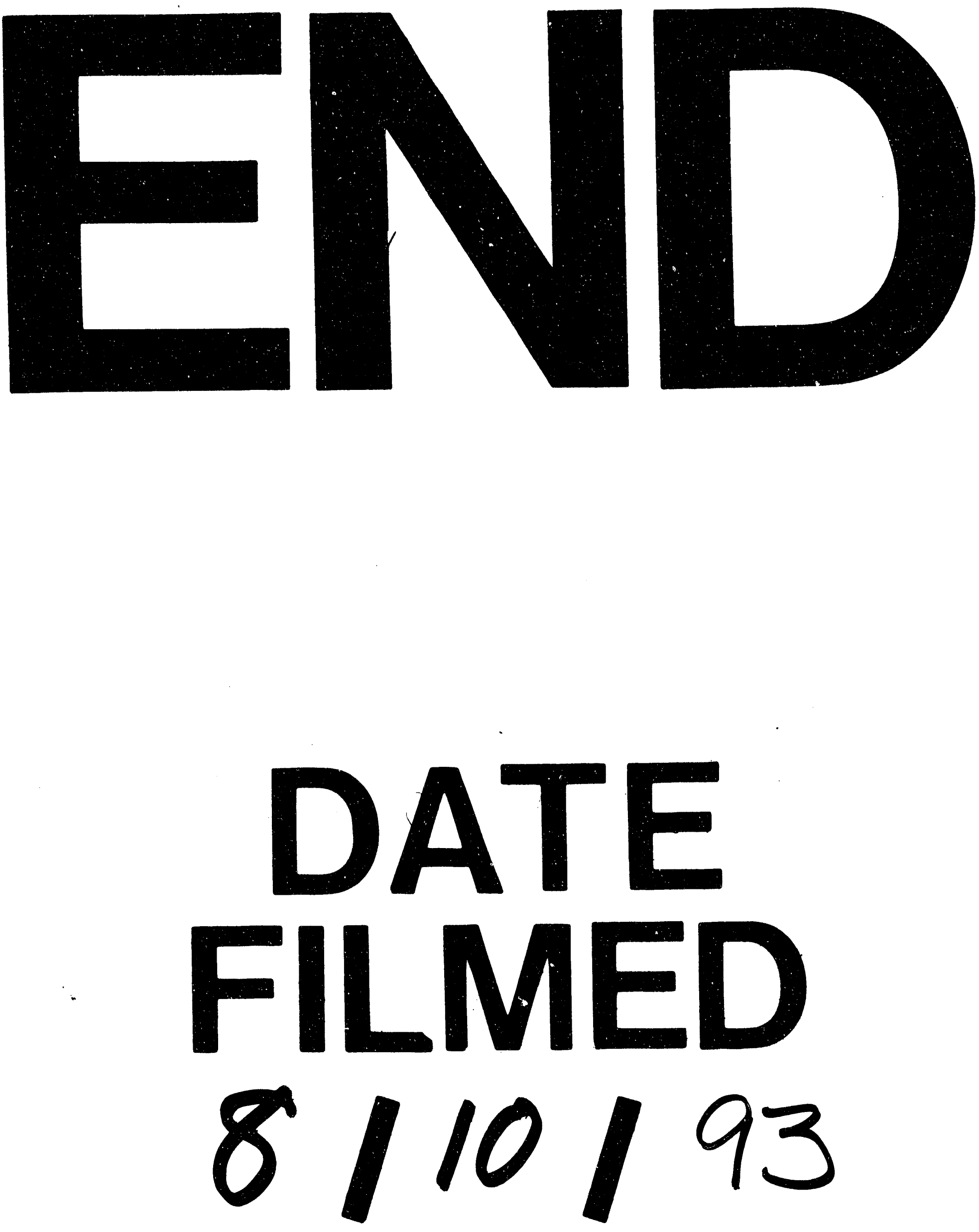
